\title{
Philosophical Bases of Interpretation of Islamic Law and its Role in the Adaptation of Islamic Prescriptions to Present Realities
}

\author{
Yu.V. Nedil'ko* \\ Kuban State Agrarian University \\ 13 Kalinina Str., Krasnodar, 350044, Russia
}

Received 11.02.2017, received in revised form 28.02.2017, accepted 24.03.2017

The article presents the research of adaptation of the ancient Islamic directions to the contemporary public relations. It is found, that in order to achieve the set objectives Muslim jurists resorted to interpretation of the legal norms based on rationalistic methods, as it helps to avoid conflicts between Islamic and secular norms, instilling legislative systems of Muslim states with qualitative originality.

Keywords: interpretation of law, rationalistic methods of interpretation, Islamic law, ijtihad, taqlid, The Quran.

DOI: $10.17516 / 1997-1370-0064$.

Research area: philosophy, law.

\section{Introduction}

Active public relations development of is associated with technological and economic progress which began back in the $19^{\text {th }}$ century and is still going on today. Such progress requires modernization of the legal systems of different countries; the countries, where the regulation of social relations is carried out by Muslim religious and legal power, are not an exception.

However, existing Islamic norms are not enough to perceive the political, economic and social institutions as fundamentally new. The situation is complicated by the fact that the need for reformations is blocked by the demand for resolution of Muslim religious and legal norms, which has been cultivated in Islamic society for centuries, and which, according to Islamic jurists, initially contained the answers to all issues raised or likely to rise before the society, due to their proper interpretation.

Due to this postulate, Muslim jurists tried to adapt the ancient rules of Islamic law to modern public relations. The most active processes of adaptation of Muslim norms to changing realities have been going on since the nineteenth century.

In some cases, the reformed political, social and economic relationships raised the question of the necessity to review many Islamic provisions, and it must be remarked that this situation has often led to numerous disputes between different

(c) Siberian Federal University. All rights reserved

* Corresponding author E-mail address: jvna@list.ru 
Muslim jurists. Due to this fact, during of the New Age and the contemporary era, the interpretation of legal norms does not remains an acute problem in countries of Muslim legal family, and with the account of evolution in all spheres of human life, we can say that it takes on more and more significance.

\section{European experience and its adaptation in Muslim countries}

Intensive western scientific and technical progress of the 19-20th centuries motivated the reformist groups of the Islamic society to act in their own states, which sometimes was impossible without reformation of Muslim regulations and rules. Therefore, nowadays a number of Islamic scholars do recognize the necessity of free and rational interpretation of the Quran, adapting it to the modern situation. One of such scholars was, for example, Mohammed Abdo: he rejected the statement that Islam doctrine and law were finally formulated by the medieval theologists. On the contrary, he advocated the mujtahids' right for interpretation of the Quran and their decisions concerning the matters of fiqh and new ijma in accordance with modern requirements. According to Abdo, every generation has the right to return to the original sources of religion and interpret them in the light of the changing circumstances and in accordance with their own worldview ${ }^{1}$.

According to Abdo, the role of Sunnah as a source of law contributing to the interpretation of the Quran was extremely restricted. Recognizing the authenticity of the small part of Hadiths, Imam considered most of them as later fake insertions. In addition, the mission of the Prophet, in his opinion, was restricted to the transmission of the Scripture, and in their actions and interpretations he could be wrong for he was an ordinary man². Subsequent generations of people, according to the views of Abdo, have all chances to interpret the position of Islam and Muslim law more properly, for they possess not only knowledge, but also the experience their predecessors did not have.

The conflict between the Tradition of the Prophet and mind, should, according to Abdo, be resolved in favour of the latter ${ }^{3}$. This position allows to take the Imam to the supporters of Kalam - a speculative approach giving the tenets of Islam an interpretation based on reason, not on an adherence to religious authorities ${ }^{4}$. According to the perspective of M. Abdo, should any irreconcilable conflicts between science and religion be detected, one must leave them to Allah and to His understanding, for they are not subject resolution within the framework of human relations ${ }^{5}$.

Consequently, we can claim that a part of Muslim jurists recognized the need to modernize the basic religious and legal provisions of Islam in accordance with the requirements of time through the use of rationalistic methods and techniques of interpretation of the fundamental norms of Islamic law.

However, reasons provided by the supporters of modernization of Islamic law faced apparent resistance of followers of the revival of early Islamic norms. Religious and legal doctrine which insists on the need to return to "initial", "clean" postulates of Islam is called "Salafi". This term comes from the Arabic word meaning "ancestors", "predecessors". According to the Salafis' point of view expressed in the Islamic literature, the Mashab refers to something the companions of the prophet Muhammad and their followers, known for their piety, and the Imams of Islamic religion testified to be the great Imams of the Ummah resorted to ${ }^{7}$. Thus, the Salafis are based on those of the Islamic religious and legal submissions relied on by the prophet Mohammed and his companions, typical of early Islam. 
As a result, the appeals to return to the lifestyle and faith of early Muslim communities are specific to the Salafis. All innovations from the interpretation of the main tenets of Islam and Islamic law and to innovations from the West, are regarded by the Salafis as bid'a (innovations in the understanding of Muslims, contrary to the words and deeds of the prophet Muhammad; also classified as "error", or "heresy". Moreover, the Salafis believe that the address to others is permitted by Islam sources of interpretation and is one of the reasons why some people consider the Quran inconsistent.

It should be noted, however, that the point of view of the Salafis on banning the decision based on the arguments of reason and its sole discretion, is contrary to the conclusion which follows from the legend about the conversation of Muhammad with Muaz, in which Muaz comes to the conclusion that in the case of gaps in the Quran and Sunnah he needs to make a decision at his own discretion, which was approved by the Prophet. It is clear that such decisions can be based on norms or general principles of Sharia, systematic interpretation of its norms, but it does not prevent us from drawing conclusions using rational methods. This interpretation is the basis of ijtihad, the "gate" of which is "closed" for traditionalists, which apparently gives them a reason to insist on the need to avoid rational techniques and methods of interpretation.

But the understanding of the "closing the gate of ijtihad" as the termination and (or) constraints of the development process of new findings of fiqh is typical, as a rule, of the Sunni schools of thought. Another interpretation may only serve as a prohibition on the formation of new schools of thought, that produce new rationalist rules, techniques and methods of interpretation, not as the prohibition of ijtihad in general. In fact, traditionalists insist on choosing one of the available interpretation ("ijtihad based on preference") and prohibition of formation of a new one. In modern conditions, it is extremely difficult to adapt the provisions of the most ancient sources of Muslim law to the legal relations, and remain guided by ancient interpretations.

It should be noted that the realities of modern and contemporary time often "provoke" the refusal of a number of Islamic principles, or, what happens more often, require the selection of such interpretation that would recognize certain innovations relevant to Islam and Muslim law. So, they demand certain changes in the law of the integration of Muslim societies into global economic institutions. The solution of this issue rests in the requirement of immutability of Islamic laws. A typical example in this area is the establishment of banking system in Muslim countries.

Traditionally, Islamic law prohibits charging interests. The acquisition of profit without efforts of any of the parties falls under the Muslim concept of riba' (Arab. "growth", "increase", "gain", "usury") what is prohibited by Islam and is recognized as one of the great sins 9 . The Islamic prohibition on "capital mortification" resisted to the prohibition of riba' because the former, from the point of view of Islam, should benefit not only its owner but also the society ${ }^{10}$.

Analysis of banking legislation in various Muslim states shows a different approach to the resolution of conflicts between two Islamic provisions. So, in Iran, Pakistan and Sudan any banking transactions were prohibited to accrue interest. Trade law of Saudi Arabia also prohibits charging interest ${ }^{11}$. Such decisions, obviously, are based on literal, traditional interpretation of the Quran, where the rule prohibiting charging interest was a priority.

Kuwait approached the problem in a very different way. There is a dispositive provision in the commercial code, which prohibits charging 
interest on commercial credit; accrual of interest under the contract is up to the parties to decide ${ }^{12}$.

This problem is resolved differently if one of the parties of the credit contract is an Islamic state: it is oriented to the principle of fiqh that allows breaking prohibitions in case of emergency. Muslim states explain their engagement with credit transactions involving interest accrual with extreme need. The same is done with taxes. They are allowed only in the case if traditional sources of inflows (e.g., zakat as a donation) are not sufficient for the state structures. So, introduction of taxes is interpreted as a result of extreme need as well.

In some cases, the conflict between Islamic provisions on the prohibition of interests and prohibition on "mortification" of capital was resolved with official interpretations. For example, in 1899 the Egyptian mufti M. Abdo solved the controversy with fatwa, proving that bank deposits and interest accrual are not usury and are not classified as riba', which contributed to the introduction of the banking system in the country ${ }^{13}$. This position is very progressive even for today's researchers of Islam and Islamic law.

Such resolutions are not typical for Islamic states at present time. In most cases interpretation of Islamic law forms the basis of scientific methods and the researches are erroneous. In particular, this was stated by the Standing Committee for Scholarly Research and Issuing Fatwas in the Kingdom of Saudi Arabia ${ }^{14}$, and a number of sheikhs, including periodicals. So, Sheikh Saalih Ibn Fawzaan al-Fawzaan, the head of the Supreme Court of Saudi Arabia, in 1994, stated that the interpretation of the Quran should only based on the Quran, Sunnah and the words of the companions of Muhammad. Tafsiri based on statements unconfirmed by either the Quran or Sunnah (based on scientific theories, researches, and built on the arguments of reason) are qualified as false ${ }^{15}$. Sheikh Muhammad Ibn Saalih alUsymin cited a quite broader list of sources for interpretation of the Quran as a source of Islamic law. They were the the Quran, the Sunnah, the words of the Prophet's companions (especially those who specialized in Tafsir), the words of the followers of the companions, the companions of the Prophet dealing with the study of the Tafsir, or to Sharia or linguistic meaning of the words ${ }^{16}$. So, and now the position of some Islamic states and competent Muslim legal scholars got restricted to prohibition of secular methods in respect to interpretation of Islamic legal norms even with good purposes to adapt it to modern realities in the interests of Muslim society.

\section{New legislation formulation attempt}

However, an increasing desire to keep up with the time and at the same time to maintain the ancient Islamic regulations in Muslim countries sometimes leads to efforts to form new legislation by state structures and legal experts by means of systematic interpretation of Islamic norms and Western progressive legislation. Thus, as a result of the Tanzimat reformations (1839-1876), the Ottoman Empire adopted some regulations conglomerating modern European legislation and conclusions formed by fiqh (Constitution of Ottoman Empire), civil and criminal codes developed on the basis of the analogous French legislation, such as trade, land, commercial, journalistic codes and so on.

In some Muslim countries, the general principles of fiqh developed as a result of ijtihad are recognized to be an integral part of the Sharia law at the constitutional level. As a rule, the constitutional courts of these countries interpreting such provisions of the Constitutions, understand the Sharia principles not only as certain provisions of the Quran and Sunnah, but as "Sharia methods" and general principles of fiqh 
having the status of law source in the material sense. The most famous source embodying the principles of fiqh in legislation is "Majalla", a set of fiqh rules in civil and forensic law adopted in 1869-1876 in the Ottoman Empire ${ }^{17}$.

The Ottoman Empire and modern Turkey are great examples of the so-called "codification" of fiqh principles and development of stateestablished legislation on general regulations and principles of the Sharia and fiqh. The formation of such regulations contributed to the interpretation of Islamic law with the purpose of adaptation to modern realities, maintaining general provisions of the Sharia and fiqh in respect with social relations. Moreover, the "Europeanization" of the legislation of Muslim countries, intertwining of Western and Muslim standards in the state regulations are sometimes considered as exercise of ijtihad to the matters not expressly provided for by the Sharia.

It should be said that in fact many Muslim legal scholars realizing the need to move away from taqlid, due to the development of the society and the state, prefer to exercise interpretation that does not restrict the regulation of social relations only by medieval Islamic standards. For example, as it happened in Egypt in 1883. By that time, there had been a number of codes based on European legislation, drafted and sent for assessment to one of the oldest Muslim theological universities of alAzhar in Cairo. Having studied them, the faqih came to a very progressive conclusion for that time, claiming that a number of the provisions corresponded to the earlier findings of the fiqh. Though many of them, indeed, could not be found in traditional doctrinal sources, they did not contradict the imperative rules of Islam and were aimed to ensure the common interests of the Muslim society and the state. With regard to the provisions on the European principle (in codes with articles and chapters), it was also found consistent with the Muslim interests, since such systematization facilitates the search of relevant standards and ensures the uniformity of application. Thus, adoption of legislative acts based on the European standards was concluded to be acceptable to a Muslim country (Egypt) from the perspective of the Sharia ${ }^{18}$. But, on the other hand, since May 1980 the Sharia had been recognized as the main legislative document. It was stated in the Egyptian Constitution of 1972, after which adoption of any legislative norms contravening the Sharia was prohibited.

\section{Conclusions}

Summing up, we emphasize once again that in the modern period the main tendency of interpretation of Islamic jurisprudence is application of the ancient Islamic norms to modern public relations. In some cases, it requires rejection of the religious standpoint and reliance on philosophical interpretations based on logical techniques. Normally this approach is practiced since its goal is benefit to the entire Muslim community.

This reorientation (albeit partial) to philosophical values was also caused by the need for further development of Islamic states, introduction of scientific and technological achievements, without which the existence of economic and financial institutions, as well as cooperation of Muslim countries with foreign states is impossible.

Considering the requirement for inviolability of Islamic regulations, the resolution of the problem contributes to the interpretation of legal norms based not only on the ancient principles, but on rationalistic methods. The close intertwining of the religious and secular elements of legislation in a number of modern Muslim states, the widespread use of systematic interpretation are the main distinctive features of the Islamic states' legal systems in the modern period. 
Seyranyan, B.G. Mukhammad Abdo: the creator of intellectual Egypt, In Universal historical portal, available at: www. svitoc.ru/articles.html/Egypt/vuhammad-abduh/.

Abdo, M. (1923). Islam and Christianity versus science and civilization. Kairo, 224.

Abdo, M. (1923). Islam and Christianity versus science and civilization. Kairo, 142.

Ibrahim, T.K., Sagadeev, A.V. (1991). Islam: encyclopaedic vocabulary. Moscow, 128-129.

Hourani, A. (1962). Arabic Thought in the Liberal Ages. 1798 - 1939. N.Y. - Toronto.

Ibrahim, T.K., Sagadeev, A.V. (1991). Islam: encyclopaedic dictionary. Moscow, 204.

As-Saffarini Mukhammad Ibn Akhmad. (1982). Lyauami Al-anuar al-bakhiya. Damask, T. 1, 20.

Ibrahim, T.K., Sagadeev, A.V. (1991). Islam: encyclopaedic dictionary. Moscow, 41.

Ali-Zade, A. (2007). Islamic encyclopaedic dictionary. Moscow, available at: http://slovar-islam.ru/books/R. html\#Riba11.

10 Sarbanov, U.K., Boldjurova, A.S. Islamic principles of financing in economics of Kyrgya Republic, In Express-analysis, available at: // https:// idmedina.ru//books/materials/rmforum/4/sarban.htm.

11 Fataua al-lyajna ad-daima, available at: //http://anti-shubohat.ru/viewtopic.php?f=16\&p=61\&sid=0e1545786c1a955e7a47e $1 \mathrm{cbc} 3913 \mathrm{eda}$ \#p61.

12 Fataua al-lyajna ad-daima, available at: //http://anti-shubohat.ru/viewtopic.php?f=16\&p=61\&sid=0e1545786cla955e7a47e $1 \mathrm{cbc} 3913 \mathrm{eda \# p61.}$

13 Ibrahim, T.K., Sagadeev, A.V. (1991). Islam: encyclopaedic dictionary. Moscow, 108.

14 Fataua al-lyajna ad-daima, available at: //http://anti-shubohat.ru/viewtopic.php?f=16\&p=61\&sid=0e1545786cla955e7a47e $1 \mathrm{cbc3913eda \# p61.}$

15 Ad-Daud. № 1447. 21 muharrama 1415 y.h.

16 Al-'Usaymina Mukhammad Ibn Salikh. Usul fi at-tafsir, available at: http://antishubohat.ru/viewtopic.php?f=16\&p=61\&s id=0e1545786cla955e7a47e1cbc3913eda\#p61.

17 Fataua al-lyajna ad-daima, available at: //http://anti-shubohat.ru/viewtopic.php?f=16\&p=61\&sid=0e1545786cla955e7a47e $1 \mathrm{cbc3913eda \# p61.}$

18 Mansur, A.A. (1971). Forms of government and administration in Islamic Sharia and positive legislation. Comparison of the Sharia with constitutional and administrative law of Beirut, 18-19.

\section{References}

Abdo, M. (1923). Islam and Christianity versus science and civilization. Kairo.

Ad-Daud. № 1447. 21 muharrama 1415 y.h.

Al-'Usaymina Mukhammad Ibn Salikh. Usul fi at-tafsir, available at: http://antishubohat.ru/ viewtopic.php?f=16\&p=61\&sid=0e1545786cla955e7a47elcbc3913eda\#p61.

Ali-Zade, A. (2007). Islamic encyclopaedic vocabulary. Moscow, available at: http://slovar-islam. ru/books/R.html\#Riba11.

As-Saffarini Mukhammad Ibn Akhmad. (1982). Lyauami Al-anuar al-bakhiya. Damask, T. 1.

Ibrahim, T.K., Sagadeev, A.V. (1991). Islam: encyclopaedic vocabulary. Moscow.

Fataua al-lyajna ad-daima, available at: //http://anti-shubohat.ru/viewtopic.php?f=16\&p=61\&sid= 0e1545786c1a955e7a47e1cbc3913eda\#p61.

Hourani, A. (1962). Arabic Thought in the Liberal Ages. 1798 - 1939. N.Y. - Toronto.

Mansur, A.A. (1971). Forms of government and administration in Islamic Sharia and positive legislation. Comparison of Sharia with constitutional and administrative law of Beirut, 18-19.

Sarbanov, U.K., Boldjurova, A.S. Islamic principles of financing in economics of Kyrgys Republic, In Express-analysis, available at: // https:// idmedina.ru//books/materials/rmforum/4/sarban.htm.

Seyranyan, B.G. Mukhammad Abdo: the creator of intellectual Egypt, In Universal historical portal, available at: www.svitoc.ru/articles.html/Egypt/vuhammad-abduh/. 


\section{Философские основания}

\section{толкования мусульманского права}

и его роль в адаптации

исламских предписаний

к современным реалиям

Ю.В. Недилько

Кубанский государственный аграрный университет им. И.Т. Трубилина Россия, 350044, Краснодар, ул. Калинина, 13

Статья посвящена исследованию адаптации древних исламских предписаний к современным общественным отношениям. Указывается, что с этой целью мусульманские правоведы прибегают к толкованию правовых норм, основанному на раџионалистических приемах. Это помогает избежать конфликтов между исламскими и светскими нормами и придает системам законодательства мусульманских государств качественное своеобразие.

Ключевые слова: толкование права, рационалистические приемы толкования, исламское право, иджтихад, таклид, Коран.

Научная специальность: 09.00.00 - философские науки, 12.00.00 - юридические науки. 